\title{
Sport Tourism and Sustainable Local Development for Host Cities for Sporting Events
}

\author{
Mohammad Saeid Kiani ${ }^{1,}$, , Leila Nazari ${ }^{1}$, Leila Shahbazpour ${ }^{2}$ \\ ${ }^{1}$ Sport Management Department, Razi University, Kermanshah, Iran \\ ${ }^{2}$ Sport Management Department, Shahrood University of Technology, Shahrood, Iran
}

Email address:

mohammadsaeidkiani@gmail.com (M. S. Kiani)

\section{To cite this article:}

Mohammad Saeid Kiani, Leila Nazari, Leila Shahbazpour. Sport Tourism and Sustainable Local Development for Host Cities for Sporting Events. American Journal of Sports Science. Vol. 7, No. 1, 2019, pp. 7-10. doi: 10.11648/j.ajss.20190701.12

Received: December 21, 2018; Accepted: January 28, 2019; Published: February 21, 2019

\begin{abstract}
The purpose of this study is to examine sport tourism and sustainable development for the host city. In the present study, in order to study sport tourism and sustainable development for the host city of sporting event, a review of the research conducted since 2009-2018 on sport tourism was used, the research methodology is a survey type based on the researcher's experiences and questions and answers from people specializing in event marketing and sports. The researcher has been looking at detailed statistics on the host of sports enthusiasts' welcome to the sporting events, and the extent to which the sport event has been sponsored by the event venue, and also expressed different ideas and ideas in order to increase the profitability of the event. Types of sports tourism users vary from sport to other sports and from event to event. In the field of policymaking for the event, it seems that there is a need for better coordination among sports organizations and organizations related to the tourism industry.
\end{abstract}

Keywords: Sport Tourism, Sustainable Development, Sports Event, Hosting

\section{Introduction}

The concept of sport-related tourism has become a popular tourism product in recent years as a study field. There is a great deal of variation in the definition of sport tourism and it is considered one of the problems of researchers [2]. In response to the question of why sport tourism suddenly became a prominent problem, one can say that by looking at history, we realize that people have participated in sportsrelated travel for centuries [6]. However, in the past ten years, the popularity of these trips has increased. Sport tourism has become the fastest growing segment of the tourism industry and is still among the booming. Major events like (Olympic Games, World Cup Final), or other sporting events (World Championships in some sports, large tennis competitions, etc.) [13]. Because of positive impacts of sport events, an increasing number of communities are planning to develop sport events or compete fiercely to host these events [11]. Researchers have not paid much attention to impacts of type of events where they recur annually with active residents' participation as competitors [5]. These events have attracted a lot of attention for a long time and provided a variety of benefits for the host cities of the event. In 2016, the global sports tourism sector accounted for $12.12 \%$ of international tourism market [18]. It is expected that tourism and travel will increase by $5 \%$ each year by 2020; the forecast for sports tourism is estimated at $10 \%$ per year [14]. Gursoy et al. (2011) assert that mega-events are part of global sport tourism, and it is not surprising that they are being pursued by emerging nations that are seeking heightened visibility and profile within the context of globalisation [10-11]. According to the World Travel and Tourism Council (2017) tourism is one of the largest economic sectors globally, with tourism associated with sport-related travel presenting major opportunities for mature as well as emerging destination [18]. Sport and tourism became major components of the globally developing entertainment industry, leaving their mark on both the material and media aspect of mass culture. As multidimensional social and cultural systems creating a network of interconnections on a local, regional, and national plane maintain multilateral relations with almost every aspect of social, cultural, and economic life, and appear to be a driving dynamic for their growth. They appear in almost 
every cultural circle in the world, building bridges and barriers between cultures, influencing national and international political decisions. Spectacular examples of the above are World Championship events and Olympic Games, which become events of cultural, media, economic, ecological, image, and political importance, especially when contests between athletes translate into contests between nations [15].

Cities and regions around the world are currently struggling to host competitions and attract tourists, and see their inherent growth and economic development in the potential that they should follow, areas that can be motivated The key to understanding the power of sports tourism can be to make the most of it. Hosted applicants regarding the potential of sports as a tourist attraction can benefit from research on sports tourism at the university [24].

There are a plethora of definitions of sport tourism, but little effort has been made in this regard; The conceptualization of the region is a typical example of many of these definitions given by Master in 1999. "All active and inactive forms of sports activities, which were normally or organized in a non-commercial or business-related manner, provide the necessity of traveling away from home and work". Such a definition, while allowing for a comprehensive approach to the study of sport tourism, is slightly broader than the current definitions of sport [3]. Bale (2003) has tried to classify "sports tourists" (for which sport is the main purpose of travel) and classify these categories more "hard" and "soft" participants; however, defects in This is because it depends on the definition of tourism activity in terms of sports or sports activities in terms of tourism, and thus inevitably creates a subordinate [1].

Tourism also includes visiting places outside the normal environment. Of course, considering the interaction of these sports and tourism features, we can see the conception of Weed and Bull (2004) that consider sports tourism "as a result of the unique interaction of activity, people and place." Here, the focus is on the "interaction" of activity, individuals, and place, thus emphasizing the nature of the synergy of the phenomenon and its movement towards its dependence. Sports or tourism are the main determinant factors. Therefore, one can think of a phenomenon that is related to sport tourism, but this is a broader topic than sports and tourism; this has caused Sport tourism cannot be recognized as a type of tourism [25].

Sports have grown over the last few years and demand for television shows has increased for sporting events, and the city's attraction for hosting sporting events has grown. Therefore, distinction should be made between financial priorities, which are typical in the United States of America and social benefits that are common in Europe, if this trend is gradually replaced by the emergence of private associations and volunteers, Makes the hosting process change [8]. However, sport tourism not only involves participating in competitions and seeing the event, it also includes outdoor sports in nature and enjoying the environment and the host city for the participant. Sports enthusiasts also visit sports or museum sites; this is not necessarily possible without the planning and presence of the leader; in advance of work, while at the same time, assigning an active part in the sport its necessary. The local institutions' movement seeks to attract these customers by reinforcing sporting events and, by increasing its activities to attract the environment for tourists and create new incidents, earn money [12]. Initially, the host city will showcase many innovations or through the introduction of sites of natural beauty and. Event venue attracts tourists. Each of these activities and resources are directly involved with business activities. This move will strengthen the transportation sector, hotels, restaurants, and other infrastructure of the host city. Demand in other sectors leads to the creation of work (seasonal or sustainable), as well as increased costs and, consequently, income in a region that indirectly leads to improved education and training [23].

\section{Methodology}

In the present study, in order to study sport tourism and sustainable development for the host city of sporting event, a review of the research carried out since 2009-2018 on sport tourism was used. The research method was a review type based on the experiences of the researcher and asking questions People specializing in event marketing and sports. Considering the fact that the sport tourism category has come to the fore in the last 10 years and is considered as a new topic, little research has been done on sport tourism and sustainable development, the study has been conducted by reviewing the research done in the time period It seeks to achieve the outcome of the event and the development of sporting tourism, as well as how to increase revenue for the event organizer, and looks at sustainable development in the event of a sports event [20].

In this research, the researcher investigated the past research and studies on extramural research and numerous articles on sport tourism and sustainable development, and compared them with each other, as well as with questions and answers from experts in the field of event holding and sports market specialist sports events and reviews. Different aspects of the event for the host city and the study of how to attract tourists at the sporting event have achieved favorable results for the development of tourism at the sporting event and have provided favorable strategies for attracting tourists and building optimal infrastructures for the host city.

\section{Findings}

The researcher has been looking at detailed statistics on the host of sports enthusiasts' welcome to the sporting events, and the extent to which the sport event has been sponsored by the event venue, and also expressed different ideas and ideas in order to increase the profitability of the event. Types of sports tourism users vary from sport to other sports and from event to event. Types of sports tourism users vary from sport to other sports and from event to event. General statistics show that most sports tourists are men between the 
ages of 18 and 34 who are in middle-class economies, a deeper study of the age group of the participants leads to a more precise outcome; for example, Cricket and rugby fans are generally older and have a higher income than fans of football and basketball. While different sports have different sports users, but all disciplines have been increasing in recent years with increasing attractiveness and popularity [9].

Sporting tourism will therefore help local development to be hosted:

Participants or viewers are the consumers and developers of the host city of the event. The people who live in the event are people who provide services to the participants and spectators, which increases their social and economic activity, and all of these are positive signs that the effect It has a positive impact on the quality of life of the host population [19].

Sport tourism thus helps to improve the quality of life of the host city:

To create a partnership between the stakeholders of a city or a region in which, through participation in the sport, its facilities can be incorporated into local assets and, as decision-makers in their responsibilities, agree and cooperate in holding and sustainable development strategies [17].

Sport tourism thus helps visitors to set up local development strategies:

The fifth iranist conference wants to highlight three dimensions: the contribution of sport to local development, quality of life, and collaboration among local decision makers to achieve the best social and economic outcomes for the host city of the event. The conference will be organized in cooperation with the International Association for Education and Training, which will allow for the implementation of methodology for conducting international research, and joint considerations of researchers and experiences acquired through education [21].

Sports Tourism and sports events Behaviors:

The above conceptual discussion leads to a discussion of the fields of research and understanding in sport tourism. Chris Bull's book (along with Chris Bowl) aims to discuss the effects of three sets of stakeholders, including participants, policymakers and providers of sports tourism, which, if these regular stakeholders are together, Consequently, the focus on stakeholder engagement can be effective [4].

Weed and Bull (2004) introduced the sport tourism partnership model, and in this model some key questions were addressed to sports event tourists [25].

Why do people go to sporting events?

What do people expect from sporting events?

How do sports tourism behaviors relate to the continuation of the trip?

What is the role of sporting events in the role of travel?

Travel decisions?

The following section tries to examine some of these questions through the provision of sport tourism participation model:
In the Sports Tourism Partnership Model, which Weed and Bull (2004) suggested, the quotas that sport tourism could have depends on understanding the identity of individuals, and found that sport tourism could even be for people who Their actual participation is important [25].

What sport is known as tourism?

There are many definitions of sport tourism and tourism. Beliefs are based on the fact that sport tourism creates incentives for people who travel, attend or watch sports, go to a sports attraction or take part in a sporting event [22].

The key sectors in the industry are:

Great Events: Olympic Games

Signature Events: Six Nations Rugby

Competitions: running, cycling, triathlon, adventure competitions, dramatic games such as medical games

Spectator: attending sports events

\section{Conclusion}

Sport tourism is a growing industry, which, as an influential factor in economic and social reconstruction and sustainable development, promotes the development of the host city and the rapid development of urban and rural areas in developing countries. Tourism is a major component of sport. Tourism has attracted a lot of attention in many countries and has recently attracted a huge share of the "domestic market". Efforts to develop and promote sports facilities and services in the host city, and efforts to increase security, amusement, transportation, health and nutrition, and the improvement and development of the quality and quantity of residential centers, including hotels, metro for the use of tourists As well as the optimal use of tourist attractions in sport events in order to increase the number of visitors and tourists and to improve the quality of facilities and increase their number at the regional and international levels to meet the needs of sports tourists, the program Design and implement various programs and co-operative events at provincial, national and international levels Nations with proper timing and location to attract more sports tourists, conduct marketing activities for informing and attracting sports tourists to the host city of sports events, as well as designing and developing an information management system for the development of sport tourism in recreational areas Increased. If this trend is to be gradually replaced by the emergence of private associations and volunteers, it will change the hosting process, in such a situation, facilities will be cheaper to build and also after the event. Can be used by local residents.

It seems that in the field of policy making, the need for better coordination among sports organizations and organizations related to the tourism industry is needed and further research is needed at the research level, in particular Research on knowledge bases in both sport and tourism has been studied.

In any case, the importance of tourism cannot be ignored in the present world. Many consider the importance of tourism as creating incomes and job opportunities, while the 
importance and majity of tourism is not limited to economic benefits. In the case of planned planning and development, tourism is able to improve the indicator Social justice, living standards, general welfare, regional balance and balance.

\section{References}

[1] Bale, J. (2003), “Sports Geography (2nd edition),” London: Spon.

[2] Brown, M and M. Nagel (2002), "the Size of the Sport Industry in the United States: Understanding (Ed)," 10 European Sport Management Congress: Future of Sport Management Proceeding, Firenze: Italy: EAS.

[3] British Tourist Authority (1981). Tourism in the UK - The Broad Perspective, London: BTA.

[4] Bull, C. J. \& Weed, M. E. (1999), 'Niche Markets and Small Island Tourism: The Development of Sports Tourism in Malta'. Managing Leisure, 4(3).

[5] Chen, k. Gursoy, D. Lau, K. (2018). "Longitudinal impacts of a recurring sport event on local residents with differentlevel of event involvement". Tourism Management Perspectives. 28, 228-238.

[6] Daniel S. Mason, a, and Gregory H. Duquettea, (2008). "Exploring the relationship between local hockey franchises and tourism Development". Tourism Management. Volume 29, Issue 6, Pages 11571165.

[7] Evangelia Kasimatia, b. (2003). "Economic aspects and the Summer Olympics: a review of related research". international journal of tourism research. 5.433- 444 .

[8] Evangelia Kasimatia, b, and Peter Dawson,a, (2008). "Assessing the impact of the 2004 Olympic Games on the Greek economy: A small Macroeconometric model". Economic Modelling. Volume 26, Issue 1, Pages 139-146.

[9] Evangelia Kasimati a,b. Peter Dawson. (2009).Assessing the impact of the 2004 Olympic Games on the Greek economy: A small macro econometric model."26.139- 146.

[10] Gursoy, D., Chi, C., Ai, J., \& Chen, B. (2011). Temporal change in resident perceptions of amega-event: The Beijing Olympic Games. Tourism Geographies, 13, 299-324.

[11] Gursoy, D., Yolal, M., Ribeiro, M. A., \& Panosso Netto, A. (2017). Impact of trust on local residents' mega-event perceptions and their support. Journal of Travel Research, 56 (3), 393-406.

[12] Holger Preuss, Benoit Seguin and Norm O, Reilly, (2007)." "Profiling managing sport event visitors: The 2002 commonwealth games". vol. 12. pp. 5-23.
[13] Kasimati, E. (2003)." Economic aspects and the Summer Olympics: a review of related research." international journal of tourism research.5.433- 444.

[14] Kwang Min (2004). "Developing Taekwondo as a tourist commodity”. IJASS, 13 (2), 5362.

[15] Malchrowicz-Mosko, E. Poczta, J. 2018." A Small-Scale Event and a Big Impact-Is This Relationship Possible in theWorld of Sport? The Meaning of Heritage Sporting Events for Sustainable Development of Tourism-Experiences from Poland. 1-19.

[16] Olympic Report, (2006). "European Tour Operators Association". Retrieved from http://www.etoa.org/docs/default-source/Reports/ETOAreports/2006-etoa-olympic-report.pdf.

[17] Sydney Olympic Games Review Committee (1990). "Report to the Premier of New South Wales". Sydney: Sydney Olympic Games Review Committee.

[18] Swart, K. Tichaawa, T, M. Odounga Othy, J, D. Daniels, T. (2018). "Stakeholder Perspectives of sport tourism Development in Gabon-A case study of the Africa cup of Nationals". Euro Economica. Issue10 (37). 177-189.

[19] Technavio (2017). Sports and wanderlust combine profitably with sports tourism. Retrieved August 16, 2017, from https://www.technavio.com/blog/sportswanderlust-combineprofitably-sports-tourism.

[20] Tekin, A., \& Tekin, G. (2014). “Antik Yunan Dönemi: Spor ve Antik Olimpiyat Oyunları". Journal of History School (JOHS), 7(18), 121-140.

[21] Thornton, G. (2013). Post-Games Evaluation Meta-Evaluation of the Impacts and Legacy of the London 2012 Olympic Games and Paralympic Games Summary Report.

[22] Tunçdemir, C. (2013). Olimpiyat Ev Sahipliğini Kazanmak Gerçekten Kazandırıyor mu? Retrieved from http://t24.com.tr/yazarlar/cemal-tuncdemir/olimpiyatevsahipligini-kazanmak-gercekten-kazandiriyor-mu, 6423.

[23] Türkiye Milli Olimpiyat Komitesi. (2013). 2013 Mersin Akdeniz Oyunları. Retrieved from http://www.olimpiyatkomitesi.org.tr/olimpikoyunlar.aspx?id= 7.

[24] Weed, M. E. (2006) 'The Story of an Ethnography: The Experience of Watching the 2006 World Cup in the Pub'. Soccer in Society, 7(1), 76-95.

[25] Weed, M. E. \& Bull, C. J. (2004), Sports Tourism: Participants, Policy and Providers. Oxford: Elsevier.

[26] Yao, Q. Schwarz, E. 2018. "Impacts and implications of an annual major sport event: A host community perspective". Journal of Destination Marketing \& management. 1-9. 